\title{
Types and Attributes of English Writing Errors in the EFL Context-A Study of Error Analysis
}

\author{
Hsiao-ping $\mathrm{Wu}$ \\ Texas A\&M University, San Antonio, TX, U.S.A. \\ Esther V. Garza \\ Texas A\&M University, San Antonio, TX, U.S.A.
}

\begin{abstract}
This study seeks to explore five $6^{\text {th }}$ grade EFL learners' major writing problems by analyzing the nature and distribution of their writing errors and it also investigates factors that cause errors in their writing in English through email communication. This study examined EFL learners' writing samples and followed taxonomy: grammatical, lexical, semantic, mechanics, and word order types of errors. Findings showed that participants made more mistakes on interlingual/transfer errors than on intralingual/developmental errors. Students used their L2 habits, rules, and patterns in the second language writing. However, students also had intralingual errors due to the overgeneralizations and partial exposure to the target language. In addition, students also included internet linguistic features in their writing. Some implications are drawn this study. First, for learners, error provided indications for teachers to understand what grammar is difficult for EFL learners. Teachers can include these errors in the teaching. For teachers explicit instructions on different errors are needed, and teachers should provide a context where fluent and accurate language use should be modeled to learners.
\end{abstract}

Index Terms - error, error analysis, interlanguage, intralanguage, second language acquisition

\section{INTRODUCTION}

English learners' errors should be analyzed carefully because these errors show the process of learning a language. The learners' errors are very important providing "insight into how far a learner has progressed in acquiring a language and showing how much more the learner needs to learn" (Ringbom, 1987, p.69). Traditionally, writing is defined as the paper-based modality; however, many writings todays are happening through computer-based medium. Today's learners use computers as a tool to learning, and teachers have to adopt the use of technology to teach.

Many studies (Kim, 2011; Li \& Zhu, 2013; Vurdien, 2013) have employed computer-mediated communication (CMC) in the language learning in the different contexts. CMC can be either synchronous or asynchronous. Synchronous communication is often referred to as real-time communication (e.g., chat, Messenger). Asynchronous $\mathrm{CMC}$ refers to communication is not real time. Both of users have to wait and receive the message in a delayed time. For example, email is the most popular form of asynchronous CMC. Many foreign language studies have included the use of email to develop writing skills (Chaffee-Sorace, 1999; Levy, 1997). This study continues to use the benefits of email in English as a foreign language (EFL) context in order to conduct an error analysis on EFL learners' writings. This study is significant because it includes the error study in a new learning context. The study would provide a clear linguistic feature analysis via email for educators and researchers.

\section{LITERATURE REVIEW}

\section{A. Error Analysis (EA)}

Error analysis is a type of approach to analyze a second/foreign language learners' speech or written performance. Several researchers already discussed error analysis from different perspectives. Corder (1967) and Brown (2000) both highlighted that language learners' errors are important to study because it shows the state of the learners' knowledge. Corder (1967) stated that error analysis are not just something to be eradicated, but rather can be important in and of themselves. Corder (1967) noted that students' errors should be not ignore because they are these errors are developing features for language learners. As was pointed by some researchers (Coder, 1967; Dai \& Shu, 1994), error analysis is highly significant for second language acquisition in the following aspects. From Corder's perspective (1981), teachers can understand students' current level in learning. For researchers, they can understand how language is learned and structured. For students, they can utilize these errors as a learning device to improve their language proficiency. Based on these three aspects, this study would like to continue to examine more cases in EFL contexts.

\section{B. Types of Errors}


In the second language acquisition, different typed of errors were defined. There are two major different types from the analysis of learners' oral and written performance. First, it is called intralingual/developmental error. According to Richards (1974), these errors are produced by the learners which reflect not the structure of the mother tongue, but overgeneralizations based on partial exposure to the target language. Overgeneralization generally involves the creation of one deviant structure in place of two regular structures, for example, "He can sings", "We are hope", "it is occurs". Second, interlingual/transfer errors (Selinkker (1974) referred the negative interference from the learner's first language habits. For example many EFL learners think in their first language and they used direct translation when they speak and write in L2.

\section{Writing through Email in Different Contexts}

This section reviewed the literature that discussed the benefits of using email in learning writing, so the following studies informs this study to use email as the medium to observe students' writing. Many benefits were found to support the language learning through email. For example, language learning occurred through constant communication, so Cooer and Selfe (1990) found that the email can generate more communication. Similarly, Pratt and Sullivan also found that the use of email increased the oral communication. Based on these two studies, namely, learners had more output in using the target language. In addition, learning a second/foreign language could be very stressful for students. Students' affective filter would be very high if they were asked to use the language face to face. Thus, Kern (1995) and Sullivan (1993) found that students felt less anxious when they joined the online discussion. For example, students were allowed to have more time before they write. They can draft their writing in an asynchronous manner. However, the face-to-face communication generated a lot of emotional stress. For example, Hoffman (1996) stated that the anonymous or nonface to face interaction can serve as a face-saving (p.55). Namely, language users will not feel embarrassed when produced the wrong usage of language.

In addition, students noted that the communication is more authentic thought email. They can reach different audiences and received feedbacks and comments from their email pen-pals. Furthermore, the study conducted by Warschauer (1996), this study found that students who joined in the email writing group improved their writing skills. With these benefits, this study continues to use this medium to examine the EFL learners' errors. However, these studies did not analyze errors of language produced in computer-mediated contexts; therefore, this study would like to explore error analysis through asynchronous email writing by EFL students.

\section{Previous Studies}

Error analyses studied have been conducted in the English as a second or foreign language context. These studies are important to be conducted because students' errors always can provide knowledge how the language is learned, and it provided the information to teacher to revise their lessons. In the ESL context, Dulay and Burt (1973) examined Spanish-speak children's writing, and this study found that $85 \%$ developmental errors. Namely, this is natural to encounter those errors when developing the accuracy. In this study, interlingual errors were not significantly found.

In the EFL context, Alhaysony (2012) examined written samples of 100 first-year female Arabic-speaking EFL students in the University of Ha'il. The findings showed that students made a considerable number of errors in their use of articles, especially, the omission errors. This study had a mixed finding because these errors included interlingual and intralingual transfer. Brown's (1994) study found that intralingual errors overtook interlingual errors. Brown concluded the overgeneralization of target language could cause errors on English learning. In Hong Kong, Chan (2004) studied 710 Hong Kong Chinese ESL students. There are 5 types of error found. This study found out that students used the syntactic transfer from Chinese to English. Therefore, it caused the run-on sentence and incomplete ideas.

Specifically, some studies were conducted in the same context like this study. Huang (2001) investigated the nature of distribution of different grammatical errors made by 46 English majors of a Taiwanese university. This study found the top six common errors were (1) verb (2) noun (3) spelling (4) article (5) preposition and (6) word choice. These errors were due to overgeneralization, ignorance of rule restrictions, simplification, incomplete application of rules and L1 negative transfer. Huang (2006) analyzed 34 Taiwanese English majors' writing errors based on a web-based writing program. This study found that $55 \%$ errors are on the usage. Namely, subject-verb is the main area EFL students need to study. Huang's study (2006) also found the errors on mechanics, style, and grammar, and these errors are transferred from the EFL students' L1. Among these previous studies, there was no agreement found in these studies; therefore, this study will continue to explore errors on EFL learners in Taiwan.

\section{METHOD}

\section{A. Participants}

The participants for this study consisted of five $6^{\text {th }}$ grade EFL students in an elementary school in Taiwan. Participants spoke Mandarin Chinese as their first language. They are learning English as a foreign language at school. Participants attended this public school and they began receiving formal instruction of English as they are in the first grade. In this context, they have very limited opportunities to communicate in English outside of school. Second, these participants were similar in age, ranging from 11 to12 years old. Namely, they have developed a certain language proficiency in using English. Therefore, they were able to produce data for analysis. 


\section{B. Data Collection Procedures}

To collect the data, participants were administrated a writing assignment that involved essay writing. They were required to write one topic assigned by the ESL teacher or self-selected by students weekly for twelve weeks. They were required to write through email.

Their writing samples were sent to an English-speaking pre-service teacher in the U.S. These native speakers were pre-service teachers who took a course of second language acquisition and literacy development in a teacher preparation program. These teachers were to be certified as an English as a second language (ESL) teacher or bilingual teacher in Texas. EFL learners' teacher assigned them different topics to write, or they selected a topic they would like to share with the pre-service teacher in Texas. The essays were ranged from one to one and a half page in length (100-150 words). There were a number steps taken in conducting an error analysis.

Essays were collected and analyzed to check various errors and numbers and ratios were counted. Based on the framework and the research design, this study sought answers to the following questions.

\section{Research Questions}

1. What types of grammatical errors are frequently found in the compositions written by Mandarin-Chinese EFL students?

2. What factors cause these errors in EFL students' writing samples?

\section{Data Analysis}

After data collection, the following steps of error analysis specified by Corder (1974) were followed. First, each essay was examined word and word and sentence by sentence. I generated the coding categories based on all writing samples. Second, I counted the number of errors and converted it into percentage to examine the occurrence. Corder's analysis approach had been used in many previous studies (e.g. Chastian, 1990; Frantzen, 1995; Kobayashi \& Rinnert, 1992; Kroll, 1990). EFL students in Taiwan mainly learn American English, so these analysis followed the American English conventions. The step 2 and 3 in the Table I listed different types of errors. All errors were underlined and labeled.

For the second research question after analyzing type of errors, the researchers will categorize what factors cause these errors based on the distinctions between intralingual and interlingual errors. Intelligible errors will be labeled and discussed. Each researcher each researcher independently reviewed writing samples for common categories. The two authors then met to present our interpretations and arrive at a shared understanding the coding. Categories were compared for similarities, differences, and connections. Once the categories had been re-examined to determine how they were connected, the data were presented and clustered into common units of meaning or themes. Table I lists the steps to analyze each error found in the writing samples.

TABLE I.

STEPS TO ANALYZE ERRORS

\begin{tabular}{|c|c|c|c|}
\hline Steps & & Definition of steps & Examples \\
\hline Step 1 & Collect data & $\begin{array}{l}\text { Written data through email } \\
\text { communication }\end{array}$ & 40 writing samples were collected \\
\hline Step 2 & Identify errors & Different types of errors & $\begin{array}{l}\text { 1. (prepositions, articles, singular/plural, adjectives, relative } \\
\text { clause, verb tense, singular/plural, nouns, pronouns, tense, } \\
\text { articles, preposition, verb formation, subject-verb agreement, } \\
\text { and fragment) } \\
\text { 2. Word choice } \\
\text { 3. Meaning } \\
\text { 4. Use of punctuations. }\end{array}$ \\
\hline Step 3 & Classify errors & $\begin{array}{l}\text { It is an error of agreement? Is it an } \\
\text { error in irregular verbs? }\end{array}$ & $\begin{array}{l}\text { Grammatical type error } \\
\text { Syntactic type error } \\
\text { Lexical type error } \\
\text { Semantic type error } \\
\text { Mechanics type error }\end{array}$ \\
\hline Step 4 & Quantify errors & How many errors of total? & How many errors of each feature occur? \\
\hline Step 5 & Analyze source & cause of these errors & $\begin{array}{l}\text { Intralingual (developmental errors) } \\
\text { Interlingual (interference errors) } \\
\text { Intelligible error (neither developmental nor interference errors }\end{array}$ \\
\hline
\end{tabular}

\section{RESUlts}

The results of the study presented are based on the three research questions posed. The answers to the first questions focused on categories of grammatical errors, frequency of occurrence of each error, percentage of each error out of total words.

The answers to the first question include categories of grammatical errors found in the students' writing, their frequency of occurrence, and the percentage and rank order of each error type.

A. What Types of Grammatical Errors Are Frequently Found in the Compositions Written by Chinese EFL Students? 
TABLE II

TYPE OF ERRORS

\begin{tabular}{llllll}
\hline Types of error & $\#$ & Error Categories & Frequency & Percentage & $\begin{array}{l}\text { Rank } \\
\text { Order }\end{array}$ \\
\hline Grammatical errors & 1 & Verb tense & 2 & $0 \%$ & 21 \\
& 2 & Sentence structure & 77 & $10 \%$ & 3 \\
& 3 & Coordination & 49 & $6 \%$ & 7 \\
& 4 & Relative clause & 1 & $0 \%$ & 22 \\
& 5 & Singular/plural & 58 & $7 \%$ & 4 \\
& 6 & Verb omission & 58 & $7 \%$ & 6 \\
Lexical errors & 7 & Subject omission & 95 & $12 \%$ & 1 \\
& 8 & S-V agreement & 88 & 8 \\
& 9 & Fragment & 44 & $11 \%$ & 18 \\
& 10 & Noun & 35 & $12 \%$ & 15 \\
& 11 & Pronoun & 19 & $4 \%$ & 19 \\
Sematic errors & 12 & Verb & 9 & $2 \%$ & $1 \%$ \\
Mechanics error & 13 & Adjective & 22 & $2 \%$ & 12 \\
& 14 & Adverb & 30 & $4 \%$ & 20 \\
Intelligible errors & 15 & Article & 5 & $1 \%$ & 13 \\
\hline Total & 16 & Preposition & 24 & $3 \%$ & 10 \\
\hline
\end{tabular}

In the analysis (see Table II) of grammatical, lexical, semantic, and mechanics errors, most errors were found from grammatical errors. Of the 22 categories of errors identified, this study found that students had the greatest problem in the subject and verb agreement. $12 \%$ of subject-verb agreement was found. The second and third most frequent errors were found in sentence fragment and sentence structure, both of which caused approximately similar percentage of error of sentence structure and fragment (10\% and $11 \%$, respectively). The fourth and fifth most frequent errors were found in singular/plural and verb omission both of which caused approximately the same percentage (7\%, respectively). Other types of errors, such as prepositions (3\%) and fragments (3\%) were found, too. The article use and pronouns wrong usage were also found in the writing. Students had $2 \%$ error rate out of all errors.

\section{B. What Specific Type of Errors Found in Each Category?}

The interligual errors in this study are classified as follows. I have analyzed the word and sentence levels, the mechanical errors, lexical errors, and word order. A total number of interlingual errors amounted to 469 out of 780 total number of errors. There are 247 interlingual errors found from students' writing samples. There are 78 lexical categories, 24 semantic errors, and 11 mechanics errors. It is clear that the grammatical category is the dominant error category. Especially, many subject-verb agreement errors were found from writing samples. Next, the second place error is lexical error. These errors include the use of noun. Namely, the noun usage is not specific and clear to refer the meaning in English. In the third place come the word choices.

\section{What Factors Cause These Errors in EFL Students' Writing Samples?}

Table III presents the result of factors causing the students' errors. First, in grammatical errors, this study found that the participants have $72 \%$ interlingual/transfer errors and $28 \%$ intralingual/development errors. Second, in the lexical errors, $47 \%$ was found in the intralingual errors, and 53\% was found in the interlingual errors. Third, in the semantic errors, only $4 \%$ intralingual error was found, and the most of errors are interlingual (96\%). Last, mechanics errors were found due to the intralingual transfer. 
TABLE III

CAUSES OF ERRORS

\begin{tabular}{|c|c|c|c|c|c|c|c|}
\hline Type of error & $\#$ & $\begin{array}{l}\text { Categories of } \\
\text { errors }\end{array}$ & Frequency & $\begin{array}{l}\text { Intralingual/ } \\
\text { development } \\
\text { errors } \\
\end{array}$ & $\begin{array}{l}\text { Intralingual/dev } \\
\text { elopment errors } \\
(\%)\end{array}$ & $\begin{array}{l}\text { Interlingual/tran } \\
\text { sfer errors }\end{array}$ & $\begin{array}{l}\text { Interlingual/ } \\
\text { transfer errors } \\
(\%) \\
\end{array}$ \\
\hline \multirow{9}{*}{$\begin{array}{l}\text { Grammatical } \\
\text { errors }\end{array}$} & 1 & Verb tense & 2 & 2 & $100 \%$ & 0 & $0 \%$ \\
\hline & 2 & $\begin{array}{l}\text { Sentence } \\
\text { structure }\end{array}$ & 77 & 9 & $12 \%$ & 68 & $88 \%$ \\
\hline & 3 & Coordination & 49 & 35 & $71 \%$ & 14 & $29 \%$ \\
\hline & 4 & Relative clause & 1 & 1 & $100 \%$ & 0 & $0 \%$ \\
\hline & 5 & $\begin{array}{l}\text { Singular/ } \\
\text { plural }\end{array}$ & 58 & 55 & $95 \%$ & 3 & $5 \%$ \\
\hline & 6 & Verb omission & 58 & 8 & $14 \%$ & 50 & $86 \%$ \\
\hline & 7 & $\begin{array}{l}\text { Subject } \\
\text { omission }\end{array}$ & 55 & 5 & $9 \%$ & 50 & $91 \%$ \\
\hline & 8 & S-V agreement & 96 & 19 & $20 \%$ & 77 & $80 \%$ \\
\hline & 9 & Fragment & 88 & 3 & $3 \%$ & 85 & $97 \%$ \\
\hline Total & & & 484 & 137 & $28 \%$ & 347 & $72 \%$ \\
\hline \multirow[t]{9}{*}{ Lexical errors } & 10 & Noun & 44 & 35 & $80 \%$ & 9 & $20 \%$ \\
\hline & 11 & Pronoun & 12 & 4 & $33 \%$ & 8 & $67 \%$ \\
\hline & 12 & verb & 35 & 3 & $9 \%$ & 32 & $91 \%$ \\
\hline & 13 & Adjective & 19 & 4 & $21 \%$ & 15 & $79 \%$ \\
\hline & 14 & Adverb & 9 & 2 & $22 \%$ & 7 & $78 \%$ \\
\hline & 15 & Article & 15 & 10 & $67 \%$ & 5 & $33 \%$ \\
\hline & 16 & Preposition & 22 & 18 & $81 \%$ & 4 & $19 \%$ \\
\hline & 17 & Word form & 30 & 25 & $83 \%$ & 5 & $17 \%$ \\
\hline & 18 & Interjections & 5 & 3 & $60 \%$ & 2 & $40 \%$ \\
\hline Total & & & 147 & 69 & $47 \%$ & 78 & $53 \%$ \\
\hline Sematic errors & 19 & $\begin{array}{l}\text { Word choice } \\
\text { (Meaning) }\end{array}$ & 24 & 1 & $4 \%$ & 23 & $96 \%$ \\
\hline \multirow[t]{3}{*}{ Mechanics errors } & 20 & Punctuation & 34 & 25 & $74 \%$ & 9 & $26 \%$ \\
\hline & 21 & Capitalization & 13 & 11 & $85 \%$ & 2 & $15 \%$ \\
\hline & 22 & Spelling & 33 & 33 & $100 \%$ & 0 & $0 \%$ \\
\hline Total & & & 80 & 69 & $86 \%$ & 11 & $14 \%$ \\
\hline $\begin{array}{l}\text { Intelligible } \\
\text { errors }\end{array}$ & & If any & 0 & 0 & $0 \%$ & 0 & $0 \%$ \\
\hline Total & & & 780 & 311 & $40 \%$ & 469 & $60 \%$ \\
\hline
\end{tabular}

\section{DisCUSSION}

Based on the collected data, the participants had the greatest difficulty in using subject-verb agreement. The possible explanation is the influence of their first language. In Chinese, verb does not change its form with different subject. Therefore, they were not aware of changing the verb form in English.

The second and third most frequent errors were found in sentence fragment and sentence structure. There are many segmental and run-on sentences were found. One possible explanation could be the transfer from Chinese grammatical rules, and did not have comprehensive knowledge on the use of conjunctions to connect different clauses.

Third, the participants also have difficulty in choosing correct noun to express their ideas clearly. Some messages were totally obscure due to incorrect word usage in the noun phrase. The meaning was not comprehensive in English usage because many nouns were translated from Chinese. Similarly, the participants also have difficulty in word choice in the verb phrase and prepositional phrases. Semantically, the wrong word choices in their writing mislead the readers. In addition, some participants wrote very little, and this might be explained by their limited vocabulary. They could not think of appropriate words and phrases to express their ideas. Some students' writing samples were very short because they did not have too much exposure in English writing. The lack of fluency in writing also increased the difficulty to comprehend students' writing samples.

In this study, I also analyzed the attributes of different types of errors. In the grammatical, lexical, and semantic errors, students made interlingual/transfer error from their first language to English. Only mechanics errors were due the intralingual transfer. There are several explanations for the interlingual transfer in sentence structure, vocabulary use, and word choices. First, these participants did not start to learn English until $3^{\text {rd }}$ grade; therefore, their literacy skills in the first language affect heavily on their English learning. Second, the English teacher used Chinese as the instructional language to teach second language. Therefore, the model of fluency in speaking and writing was absent. The lack of fluency input could lead students' error from Chinese to English.

\section{PeDAgogical IMPLication}

There are some pedagogical implications can be drawn from this study. First, making errors are a normal language developmental process, so students' errors are great sources for improving teaching and learning. Teachers should not 
labels students based on their errors in writing. Namely, students' effort of trying should be praised, and teachers should encourage students to engage writing for different purposes in order to language in the different contexts.

Second, for specific instructional activities for subject-verb agreement, explicit instruction in each linguistic feature should be included in the classroom. Teacher can provide interactive teaching ideas for practicing different subjects and verbs usage in the different contexts. Namely, interactive games and collaborative activities are highly recommended to practice each specific feature.

Third, this study would suggest teachers should prepare students to use English in real-life settings. Namely classroom activities should be embedded to authentic audience and materials. Participants in this study expressed that they feel motivated and excited when receiving feedback from native speaker of English; thus, teachers should design authentic tasks in ways that align English language learning with students' interests and learning styles. The majority of errors are from the translation of first language. This finding would imply the model of using fluent English for EFL students in this study. Teaching can include authentic materials, such as newspapers, magazines, websites, and published reading materials in teaching. For the future teachers and students, we believe that that the encouragement; positive corrective feedback, authentic target language input, interactive teaching and learning activated the students' motivation and awareness can facilitate language development.

\section{CONCLUSION}

This study identifies different errors produced by Mandarin-Chinese speaking EFL students. This study presented different errors due to the interlingual and intralingual transfer. However, this study found that student's L1 has caused negative transfer on word and sentence levels. Namely, relying on the mother tongue is the main strategy used by the EFL learners when they compose the essay in English. However, this study would like to highlight that these errors have positive indications for language teachers and researchers. For teaching purposes, teachers need to design activities for areas needed for improvement. Teachers should keep in mind that overemphasis on errors can frustrate learners' motivation. Teachers could use these errors in class and revise the teaching activities. For students, we should allow students to learn when they are ready. In the classroom, teachers should be able to provide corrective feedbacks in a non-threatening way (e.g., recast, paraphrase, positive feedbacks) in order to raise learners' awareness to correct themselves. Teachers also should be able to model the complete sentence and lexical use in order to provide students more exposure in using English.

\section{REFERENCES}

[1] Alhaysony, M. (2012). An analysis of article errors among Saudi female EFL students: A case study Asian Social Science, 8(12), 55-66.

[2] Barker, T., \& Kemp, F. O. (1990). Computers and community: Teaching composition in the twenty first century. In C. Handa (Ed.), Network theory: a postmodern pedagogy for the writing classroom (pp. 1-27). Portsmouth, NH: Bonyton/Cook Publishers.

[3] Belz, J. A. (2002). Social dimensions of telecollaborative foreign language study. 6(1), 60-81._Language Learning \& Technology.

[4] Brown, H. D. (2000). Principles of language learning and teaching (4 ed.). Addison Wesly Longman: Longman.

[5] Brown, H, D. (1994). Principles of language learning and teaching (4 ed.). New York Longman.

[6] Chastian, K. (1990). Characteristics of graded and ungraded compositions. Modern Language Journal, 11, $367-383$.

[7] Chaffee-Sorace, D. (1999). Computer pen pals: Writing activities for subjects of foreign languages. Canadian Modern Language Review, 56(2), 251-254.

[8] Chen, H. C. (2004). Asymmetrical performances of English null subjects and null objects for Chinese college students. Paper presented at the Thirteenth International Symposium on English Teaching, Taipei.

[9] Cooper, M. M., \& Selfe, C. L. (1990). Computer conferences and learning: authority, resistance and internally persuasive discourse. College English, 52(8), 847-873.

[10] Corder, S. P. (1981). Error analysis and interlanguage. Oxford: Oxford University Press.

[11] Corder, S. P. (1974). Error analysis. In P. B. Allen \& S. P. Corder (Eds.), Techniques in applied linguistics (pp. 122-154). London: Oxford University Press.

[12] Corder, S. P. (1971). Idiosyncratic errors and error analysis. IRAL, 9(2), 147-159.

[13] Corder, S. P. (1967). The significance of learner's errors. International Review of Applied Linguistics, 5 (4), 161-170.

[14] Dai, W. Y., \& Shu, D. F. (1994). Some research issues in contrastive analysis, error analysis and interlanguage. Journal of Foreign Languages, 5, 1-7.

[15] Dulay, H. \& Burt, M. (1973). Should we teach children syntax? Language Learning, 23, 245-258.

[16] Frantzen, D. (1995). The effects of grammar supplementation on written accuracy in an intermediate Spanish content course. Modern Language Journal, 79(3), 329-344.

[17] Hoffman, R. (1996). Computer networks: Webs of communication for language teaching. In M. Pennington (Ed.), The power of CALL (pp. 55-78). Houston: Athelstan.

[18] Huang, S. J. (2006). A case study of EFL students' writing errors on a web-based writing program. Paper presented at the International Conference \& Workshop on TEFL and Applied Linguistics, Ming Chuan University.

[19] Huang, S. J. (2001). Error analysis and teaching composition (Master), National Tsing Hua University.

[20] Kern, R. (1995). Restructuring classroom interaction with networked computers: effects on quantity and characteristics of language production. Modern Language Journal, 79(4), 457-476. 
[21] Kim, H. K. (2011). Promoting communities of practice among non-native speakers of English in online discussions. Computer Assisted Language Learning, 24(4), 353-370. doi: 10.1080/09588221.2011.572899

[22] Kobayashi, H., \& Rinnert, C. (1992). Effects of first language on second language writing: Translation versus direct comparison. Language Learning, 42(2), 183-215.

[23] Kroll, B. (1990). What does time buy? ESL student performance on home versus class compositions. In B. Kroll (Ed.), Second language writing: Research insights for the classroom (pp. 140-154). Cambridge: Cambridge University Press.

[24] Kroll, B. (1982). Levels of error in ESL composition Ph.D. dissertation. University of Southern California.

[25] Levy, M. (1997). Computer-assisted language learning: Context and conceptualization. New York: Oxford University Press.

[26] Li, M., \& Zhu, W. (2013). Patterns of computer-mediated interaction in small writing groups using wikis. Computer Assisted Language Learning, 26(1), 61-82.

[27] Pratt, E., \& Sullivan, N. (1994). Comparison of ESL writers in networked and regular classroom. Paper presented at the 28th Annual TESOL convention, Baltimore, MD.

[28] Ringbom, H. (1987). The role of first language in foreign language learning. U.S.A.: Multilingual Matters, Ltd.

[29] Selinker, L. (1974). Interlanguage. In J. Richards (Ed.), Error analysis: Perspectives on second language acquisition (pp. 31 54). Essex: Longman.

[30] Sullivan, N. (1993). Teaching writing on a computer network. TESOL Journal, 3(1), 34-35.

[31] Vurdien, R. (2013). Enhancing writing skills through blogging in an advanced English as a Foreign Language class in Spain. Computer Assisted Language Learning, 26(2), 126-143. doi:10.1080/09588221.2011.639784.

[32] Warschauer, M. (1996a). Motivational aspects of using computers for writing and communication. Honolulu: University of Hawaii, Second Language Teaching and Curriculum Center.

[33] Warschauer, M. (1996b). Computer-assisted language learning: an introduction. In S. Fotos (Ed.), Multimedia language teaching (pp. 3-10). Tokyo: Logos International.

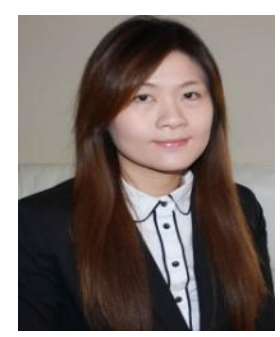

Hsiao-ping Wu is an assistant Professor at Texas A\&M University -Her teaching specializations focus on applied linguistics, second language acquisition, and research methods in ESL in order to prepare future bilingual/ESL teachers in Texas. Her current research interests include new literacies through computermediated communication (CMC), Computer-assisted language learning (CALL), and second language teaching pedagogy. Dr. Wu received her Bachelor's of Arts from Shih-Chien University in Taipei, Taiwan. Her Master of Arts from The University of Texas at San Antonio and her Ph. D. from The University of Texas at San Antonio.

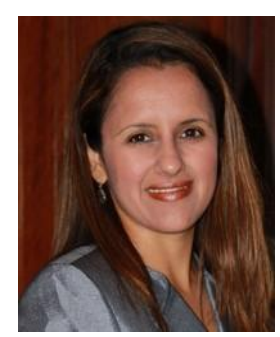

Esther V. Garza is an Assistant Professor of Bilingual Education at Texas A\&M University-San Antonio. Her research interests are in the fields of teacher preparation, biliteracy, multiculturalism and bilingual education in the content area of science. Dr. Garza received a Bachelor's of Science from Texas A\&M University in College Station, TX, her Master of Arts from The University of Texas at San Antonio and her Ph.D. from The University of Texas at San Antonio. 